\title{
70. STRUCTURAL STUDY OF BASALTIC ROCKS SHOWING BRITTLE DEFORMATION (DEEP SEA DRILLING PROJECT LEGS 51, 52, AND 53, SITES 417 AND 418)
}

\author{
P. Choukroune, Laboratoire de Géologie Structurale et Dynamique de la Lithosphere, Université de Rennes 1, \\ 35042 Rennes Cedex, France
}

\section{INTRODUCTION}

The locations of samples are shown in Figure 1 and listed in Table 1. Most of these were drilled from pillow lavas or massive basaltic formations in Layer 2 of the pre-Aptian oceanic crust. A large proportion of samples shows brittle deformation, with small-scale faulting and slickensides on fault planes; most planes are coated with secondary minerals.

\section{METHODS OF STUDYING BRITTLE DEFORMATION AT THE SAMPLE SCALE IN VOLCANIC MATERIAL}

A sample of a non-oriented core with known polarity, when subjected to microtectonic analysis, may throw light on the tectonic event - compressional or tensional - that has affected the rocks and may indicate whether the microstructures appeared during one or several phases of deformation. This analysis is based upon the presence of relative movement discontinuities separating "blocks" that have not undergone penetrative deformation, upon their behavior and upon the spatial compatibility between the geometry of the discontinuities and the observable displacement (Tjia, 1964, 1967; Badgley, 1965; Arthaud and Choukroune, 1972; Durney and Ramsay, 1973; Engelder, 1974).

The structures employed in the analysis were: striated microfaults, joints (without visible displacement), open cracks, and Riedel shears.

The displacement on fault planes is determined by the following criteria:

The striation on the fault plane indicates the direction of displacement. (Measurement is made of the angle between these striations and the horizontal line of the plane considered, i.e., the pitch.)

The relative positions of the mylonitized zones and the open zones filled by secondary minerals, those of microfaults and gashes, and the orientation of clear markers (such as plagioclase phenocrysts occurring as striating elements) indicate the direction of the relative movement.

These criteria are summarized in Figure 2.

The representation of the planar or linear structural elements is by stereographic projection on a Wulff net (lower hemisphere), north being arbitrarily defined by the horizontal line of one of the observed fault planes (Figure 3).

\section{MICROTECTONIC DATA}

The samples studied are only those showing fractures of undoubted tectonic origin; they come from pillow lavas or massive basaltic layers. The samples drilled from breccia formations that may represent old talus or rubble are not significant in this context.

The secondary minerals on microfault planes were analyzed by X-ray diffractometry; they are mainly magnesium chlorite (vermiculite) and sodium plagioclase (determination by B. Auvray, Petrology-Rennes). The open cracks are predominantly filled with calcite.

\section{Leg 51B, Hole 417D}

Three significant samples were studied in this hole.

\section{Section 41-6, Piece 3C}

This is a basaltic rock with plagioclase phenocrysts. The sample is in two pieces separated by a well-defined fault plane with a dip of $55^{\circ}$ when the core is in vertical position (Figure 3 and Plate 1, Figures 1-4).

The plane shows slickensides with a pitch of $90^{\circ}$; the protruding plagioclase phenocrysts of the lower fault plane have striated the upper fault plane. These facts make possible the determination of the relative direction of motion along the fracture, and a normal fault is thus ascertained.

A second fault plane with the same direction, but a dip of $70^{\circ}$ in the opposite sense, is also present (Figure 3); it shows slickensides with a pitch of $90^{\circ}$. This fracture can be interpreted as the conjugate of the normal fault mentioned above. Two calcitic gashes are observed with an important dip. This sample is clearly affected by a horizontal extension (X-horizontal).

\section{Section 44-4, Piece 8}

The fracture system is composed of two families which have approximately the same direction but dip in opposite directions (Figure 4). Their intersection is nearly horizontal. All the planes are covered by magnesium chlorite and are striated.

Plane a: dip $40^{\circ} \mathrm{W}$, striations pitch $15^{\circ}$. Sinistral movement with small normal component.

Plane c: dip $60^{\circ} \mathrm{W}$, curved striations. Normal fault.

Plahe b: dip $60^{\circ} \mathrm{E}$, striations pitch $90^{\circ}$. Pure normal fault.

Plane d: dip $50^{\circ} \mathrm{E}$, striations pitch $10^{\circ}$. Dextral movement with small normal component (Figure 4) (Plate 1, Figures 4-7). The deformational sequence cannot be determined at present. The data show that the deformation is complex but compatible with horizontal elongation progressively changing in direction, the displacements being controlled by the initial fracturing.

\section{Section 45-1, Piece 4}

One fault plane with a dip of $80^{\circ}$ can be observed. Two generations of slickensides are found: the earlier is thought 
LEGS 51-53 SEOINENT AND BASEMENT SIRATIGRAPHY
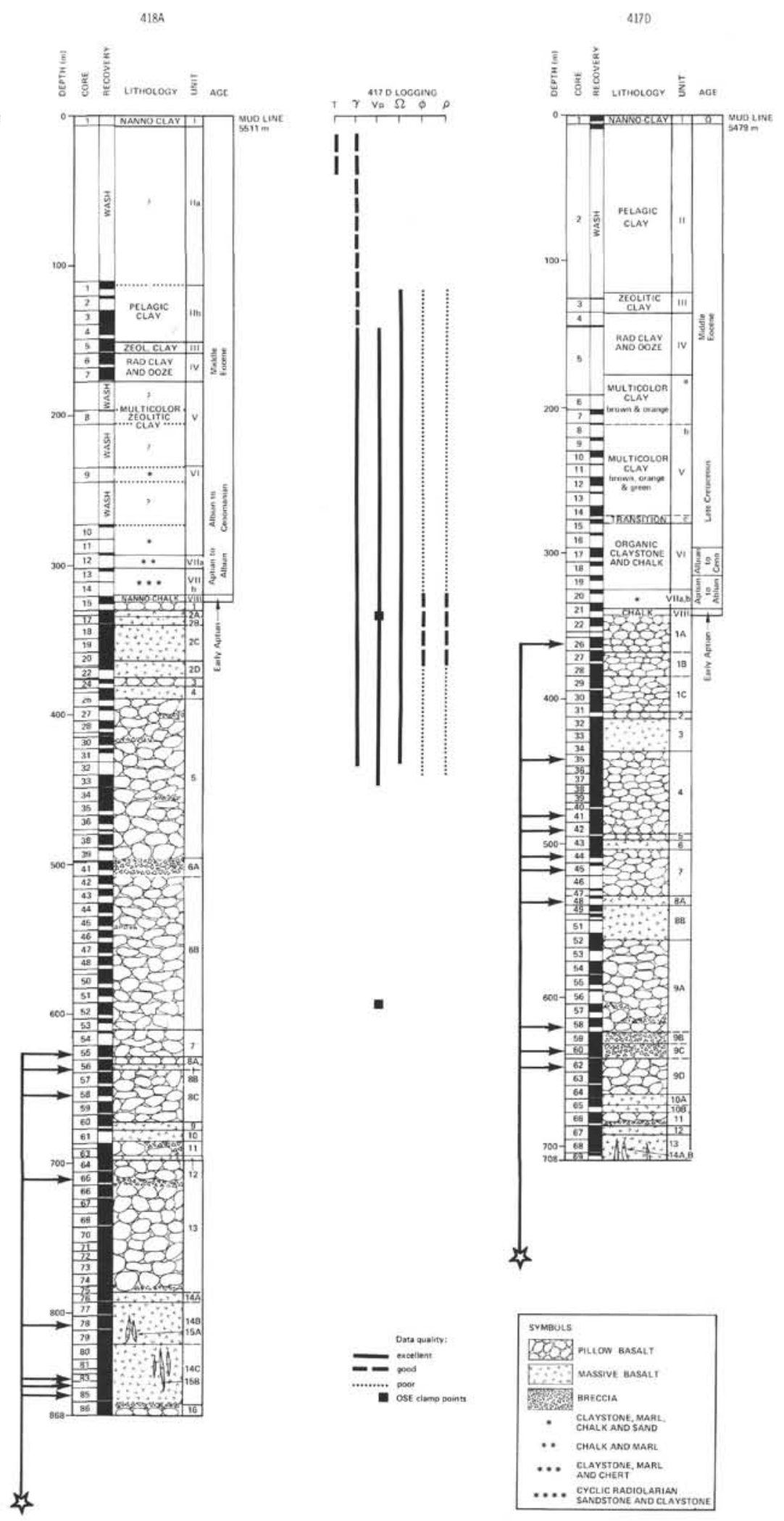

Figure 1. Stratigraphic section of Holes $418 \mathrm{~A}$ and $417 D$; the location of samples studied is indicated by arrows. 
TABLE 1

List of Samples and Their Position

\begin{tabular}{|c|c|}
\hline Leg 51B, Hole 417: & $\begin{array}{l}\text { Section } 35-2 \text {, Piece } 6 \\
\text { Section } 41-6 \text {, Piece } 3 \text { C } \\
\text { Section } 42-3 \text {, Piece } 3 \\
\text { Section 44-4, Piece } 8 \text { B } \\
\text { Section } 45-1 \text {, Piece } 4 B\end{array}$ \\
\hline Leg 52, Hole 417D: & $\begin{array}{l}\text { Sample } 26-2,114-117 \mathrm{~cm} \\
\text { Sample } 48-6,49-51 \mathrm{~cm} \\
\text { Sample } 48-6,99-102 \mathrm{~cm} \\
\text { Sample } 58-3,82-86 \mathrm{~cm} \\
\text { Sample } 60-3,102-105 \mathrm{~cm} \\
\text { Sample } 62-4,95-99 \mathrm{~cm}\end{array}$ \\
\hline Leg 53, Hole 418A: & $\begin{array}{l}\text { Sample } 55-2,116-122 \mathrm{~cm} \\
\text { Sample } 55-4,81-87 \mathrm{~cm} \\
\text { Sample } 56-2,97-102 \mathrm{~cm} \\
\text { Sample } 58-3,50-53 \mathrm{~cm} \\
\text { Section } 58-3 \\
\text { Sample } 58-4,46-49 \mathrm{~cm} \\
\text { Sample } 65-4,21-26 \mathrm{~cm} \\
\text { Sample } 78-5,88-93 \mathrm{~cm} \\
\text { Sample } 78-5,103-108 \mathrm{~cm} \\
\text { Sample } 83-3,35-41 \mathrm{~cm} \\
\text { Sample } 84-1,74-79 \mathrm{~cm} \\
\text { Sample } 85-2,27-33 \mathrm{~cm} \\
\text { Sample } 85-5,122-129 \mathrm{~cm}\end{array}$ \\
\hline
\end{tabular}

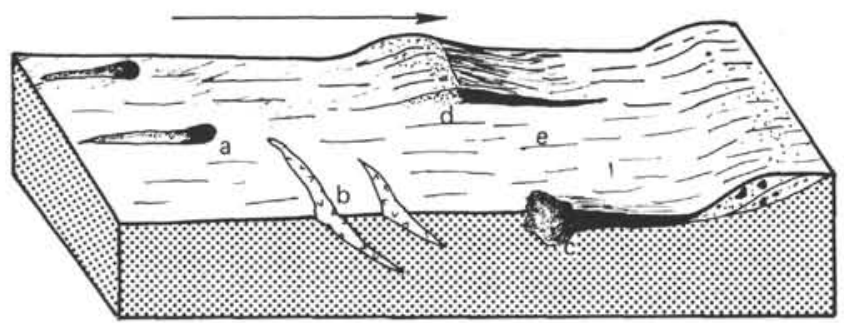

Figure 2. Diagrammatic representation of the displacement criteria on fault plane in volcanic rocks: (a) slickensides and striating elements, (b) relative position of gashes, (c) secondary mineralization - (in black) in shadow at extremity of a phenocryst, (d) secondary mineralization in shadow near an irregularity along a fault plane, (e) morphology of striations, $(f)$ brecciation on a favorable irregularity on the fault plane.

to be that with a pitch of $90^{\circ}$ and showing pure normal movement. The second generation parallels the strike of the fracture plane. This sample is the only one showing two successive movements on the same fracture.

\section{Leg 52, Hole 417D}

\section{Sample 48-6, 49-51 cm}

The sawn slab shows two families of fractures with an approximate dip of $45^{\circ}$; their intersection is horizontal. These fractures are locally opened and are filled with calcite. Crystals of one of the sets are twisted by the displacement along the plane of the other: the displacement is normal. Conjugate normal faults.

\section{Sample 48-6, 99-102 cm}

A fault plane with a dip of $30^{\circ}$ showing striations with a pitch of $90^{\circ}$ can be observed. Normal displacement is deduced from the morphology of the slickensides.

\section{Sample 62-4, $95-99 \mathrm{~cm}$}

One vertical fault plane is covered by striated vermiculite. The striations have a pitch of $25^{\circ}$. Dextral displacement is deduced from the morphology of the slickensides.

\section{Sample 62-4, 95-99 cm (one-fourth core bit)}

One fault plane with a dip of $35^{\circ}$ is present. The pitch of the striations is $45^{\circ}$. Some crystals of plagioclase and pyrite, set in place, have striated the chlorite coating. The movement has a normal component.

\section{Leg 53, Hole 418A}

\section{Sample 55-2, 116-122 cm}

The sample shows one fault plane with a dip of $65^{\circ}$; the pitch of the striations is $80^{\circ}$. Normal displacement is deduced from the morphology of the slickensides with respect to secondary chlorite crystallization zones.

\section{Sample 55-4, 81-87 cm}

One fault plane and calcitic-opened gash are present. The dip of the fault is $55^{\circ}$ and the pitch of striations is $40^{\circ}$. There is no clear coherence between the position of the fault plane relative to the gash and the normal displacement (with a dextral component) deduced from the morphology of the slickensides (Figure 5 and Plate 2, Figure 1).

\section{Sample 56-2, $97-102 \mathrm{~cm}$}

One fault plane with a dip of $50^{\circ}$ shows striations with a pitch of $45^{\circ}$. The morphology of slickensides associated with the position of an opened calcitic gash shows that the movement is reverse with a sinistral component (Figure 5).

\section{Section 58-3}

One vertical microfault with a chloritic striated surface. The pitch of the striations is $45^{\circ}$. Up not indicated.

\section{Sample 58-4, $46-49 \mathrm{~cm}$}

One fault plane appears with a dip of $60^{\circ}$. The pitch of the striations is $90^{\circ}$. The presence of striating plagioclase fragments on the chloritic surface indicates a reverse movement.

\section{Sample 65-4, 21-26 cm}

The sample shows one fault plane with a dip of $55^{\circ}$. This fault plane separates the fresh and compact basaltic rock in the lower portion from the partially brecciated basalt in the upper portion; the breccia is thought to result from tectonic movements. The striation has a pitch of $70^{\circ}$ and affects the chloritic surface. Reverse motion is deduced from the relative position of the crystallization zones with respect to the brecciated zone (Plate 2, Figures 2 and 3).

\section{Sample 78-4, 139-144 cm}

One fault plane with a dip of $40^{\circ}$. The pitch of the striations is $90^{\circ}$. The plane is largely covered by chlorite fibers and a clear reverse displacement is indicated.

\section{Sample 78-5, 88-94 cm}

One fault plane with a dip of $30^{\circ}$. The pitch of striations is $80^{\circ}$. Determination of the reverse motion is based upon the habit of secondary chlorite. 

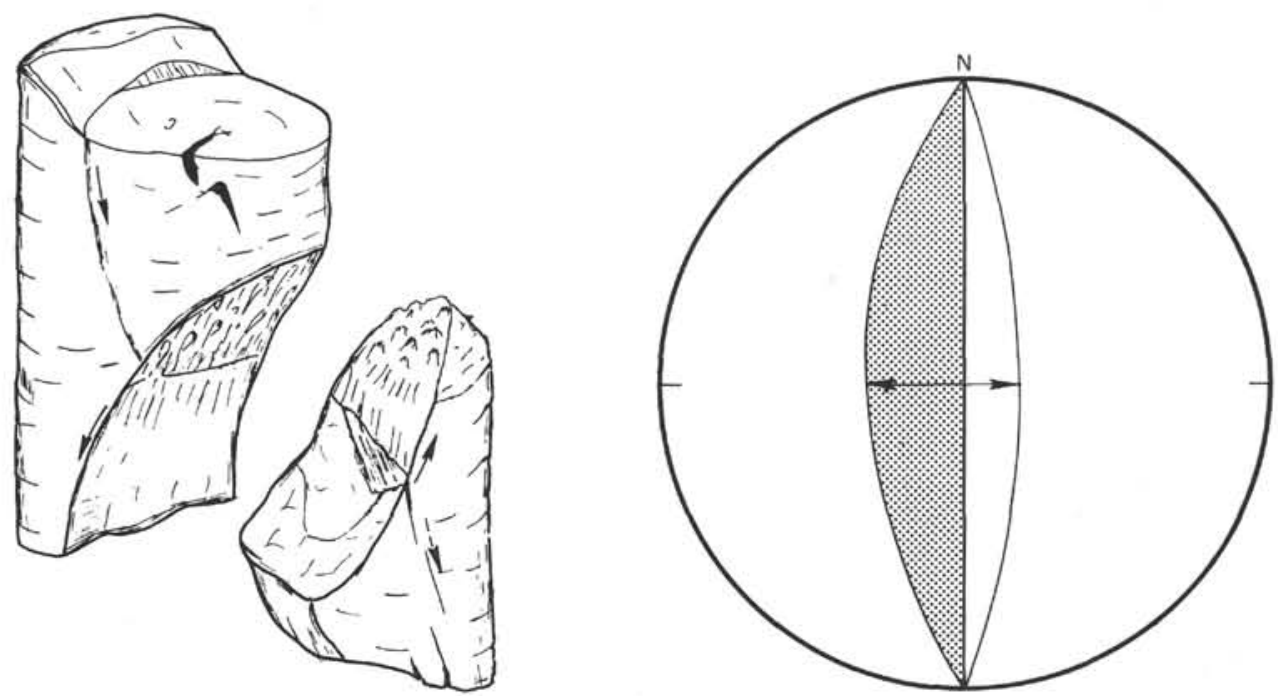

Figure 3. Structural elements shown by Piece 3C of Section 417D-41-6. The arrows represent striations on the fault plane and give the direction of the displacement along the plane (displacement of the upper block). See also Plate 1, Figures 1-4.

\section{Sample 78-5, 103-108 cm}

One fault plane with a dip of $25^{\circ}$. The pitch of striations is $90^{\circ}$. A reverse movement is indicated based on the same criteria as the previous sample.

\section{Sample 78-3, $35-41 \mathrm{~cm}$}

One fault plane with a pitch of $85^{\circ}$ (interpretation and criteria as above: reverse faulting).

\section{Sample 84-1, $74-79 \mathrm{~cm}$}

One fault plane with a dip of $65^{\circ}$. The pitch of striations is $80^{\circ}$. Reverse fault (Plate 2, Figures 4 and 5).

\section{Sample 85-2, 27-33 cm}

One fault plane with a dip of $55^{\circ}$ is largely covered by secondary chlorites. Reverse movement is clear along the striations which have a pitch of $90^{\circ}$ (Plate 2, Figure 6).

\section{Sample 85-5, 122-129 cm}

This sample is very similar to the previous one. The fault plane has a dip of $50^{\circ}$. Striations and fibrous vermiculite are $90^{\circ}$ to the strike of the reverse plane (Plate 2, Figure 7).

\section{INTERPRETATION AND CONCLUSIONS}

The principal observations of this study can be summarized as follows:

1) The drilled rocks have been subject to only one deformation phase, except in one sample which shows superposed striations. All fractures in individual samples are compatible.

2) In some cases, pre-existing fracturing seems indicated. In thin section, it appears that some glassy surfaces have been reactivated during the tectonic event and secondary chloritization.

3) The majority of dip angles of fractures are between $60^{\circ}$ and $50^{\circ}$. Dip angles less than $25^{\circ}$ do not exist. The lower dips are essentially those of reverse faults. High pitch values are dominant (Figure $6 \mathrm{a}$ and $6 \mathrm{~b}$ ).
4) Results for Hole 417D are coherent inasmuch as only tensional structures appear.

5) In Hole 418A, a great coherence is observed for reverse structures from Core 56 to Core 85 . Core 55 shows a normal fault.

Observations 4 and 5 appear to contradict each other, and they merit further discussion. With the exception of some theoretical models (Harrison, 1974), only tensional structures are widely recognized in accreting plate boundaries. To explain the compressive brittle deformation in Hole 418, the following hypotheses are:

a) Reverse faults are in fact old, normal tilted faults; this explanation is based upon the low values of the fault dips now measured.

b) For some time, the rocks have been in a condition where a lateral compression and shortening was possible (for example, near a fracture zone). However, in this case, we cannot explain the divergent results obtained for Holes 417 and 418 .

c) Compressive structures in Hole 418 represent a local phenomenon and are not the result of horizontal shortening, affecting the oceanic crust. Such structures are known, for example, in the forepart of tilted blocks along curved normal faults.

At present, the first two hypotheses seem dubious with respect to the structural context of the holes. Noticeable tilts of sharply delimited blocks have been recognized during the drilling (Bleil et al., 1977; Robinson et al., 1977); therefore the third interpretation seems the most plausible.

\section{REFERENCES}

Arthaud, F. and Choukroune, P., 1972. Methode d'analyse de la tectonique cassante a l'aide des microstructures dans les zones peu deformees, Revue I.F.P., v. 27, p. 715-732.

Badgley, P.C., 1965. Structural and tectonic principles: New York (Harper).

Bleil, U., Donnelly, T.W., and Francheteau, J., 1977. Paleomagnetic and structural evidence for a tectonic event in the Leg 51 basement, A.G.U. Abstract, San Francisco. 
Durney, D.W. and Ramsay, J.G., 1973. Incremental strains measured by syntectonic crystal growths. In Gravity and tectonics: New York (John Wiley and Sons), p. 67-96.

Engelder, J.T., 1974. Cataclasis and the generation of fault gouge, Geol. Soc. Am. Bull., v. 85, p. 1515-1522.

Harrison, C.G.A., 1974. Tectonic of mid-ocean ridges, Tectonophysics, v. 22, p. 301-310.
Robinson, P., Bryan, W., Donnelly, T.W., Flower, M.F.J., Francheteau, J., and Salisbury, M., 1977. Deep drilling in old oceanic crust: Deep Sea Drilling Project, Legs 51, 52, and 53, A.G.U. Abstract, San Francisco.

Tjia, H.D., 1964. Slickensides and faults movements, Geol. Soc. Am. Bull., v. 75, p. 683-686. 1967. Sense of fault displacement, Geologie en Mijnbouw, v. 46, p. 392-396.
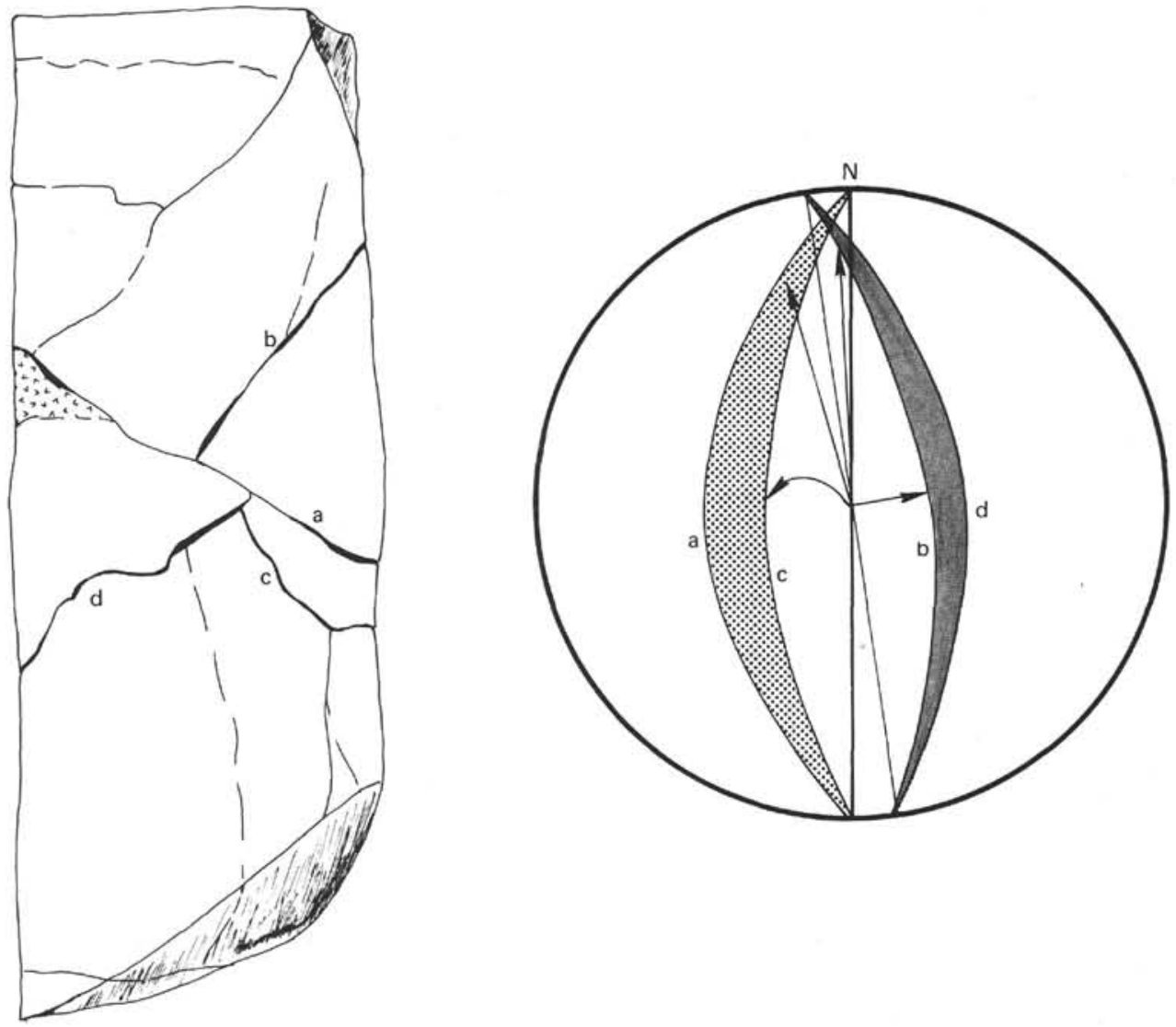

Figure 4. Structural elements shown by Piece 8 of Section 417D-44-4. For further explanation, see text. See also Plate 1, Figures 5-8.
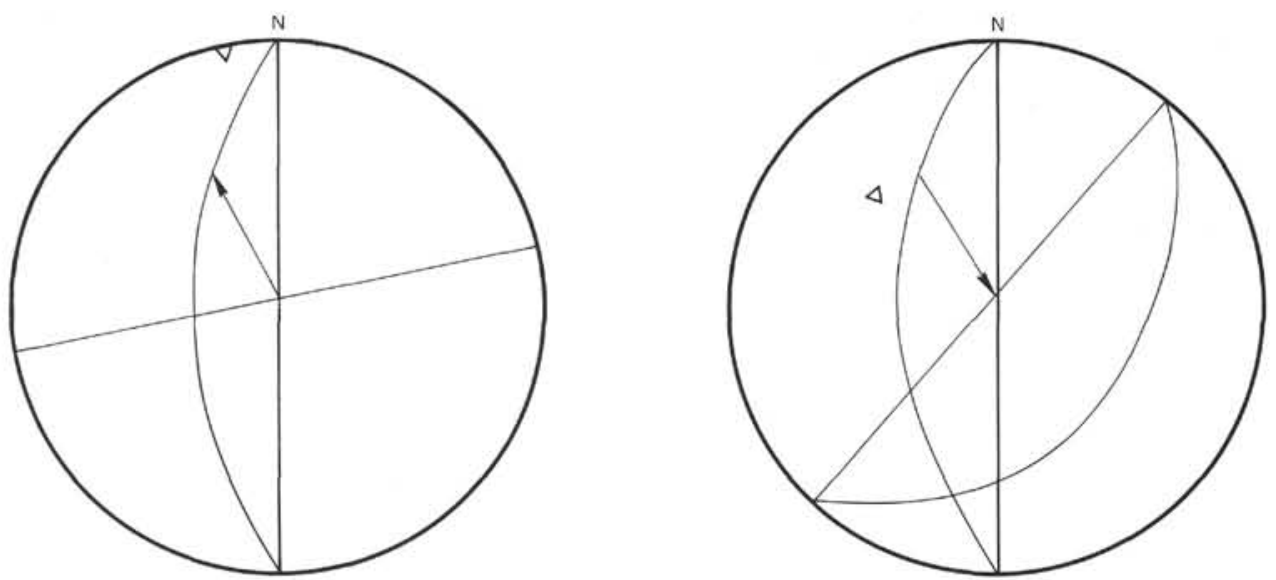

Figure 5. Structural elements of Samples 418A-55-4, 81-87 cm (left) and 418A-56-2, $97-102 \mathrm{~cm}$ (right). The gashes are represented by their plane and the pole of their plane (triangle). 


\section{P. CHOUKROUNE}
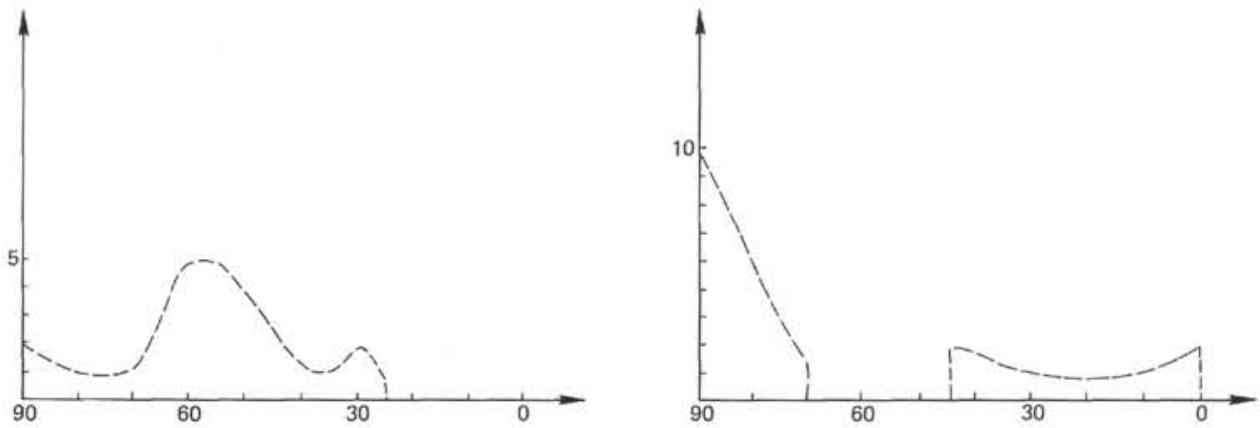

Figure 6. Values of dip angles of fractures (left) and pitch of the striations on the fracture planes (right). The majority of dip angles of fracture fall between $60^{\circ}$ and $50^{\circ}$. The high values of pitch are dominant between $90^{\circ}$ and $70^{\circ}$. 
PLATE 1
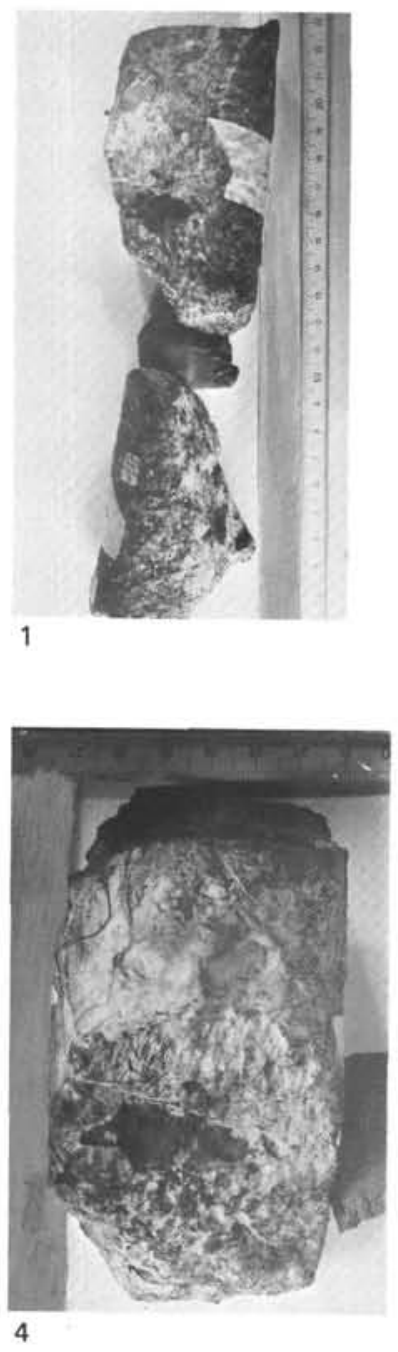

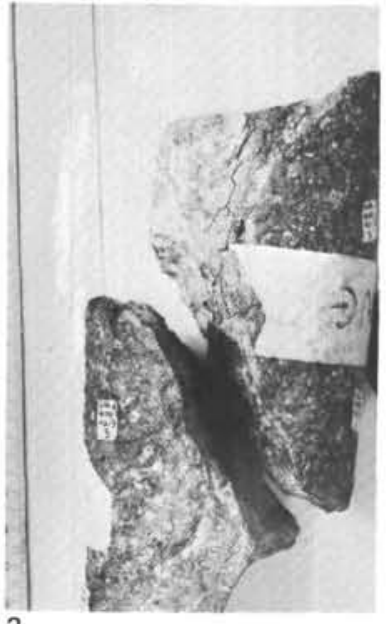

2

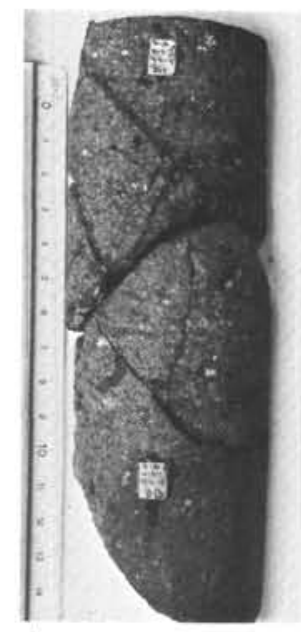

5

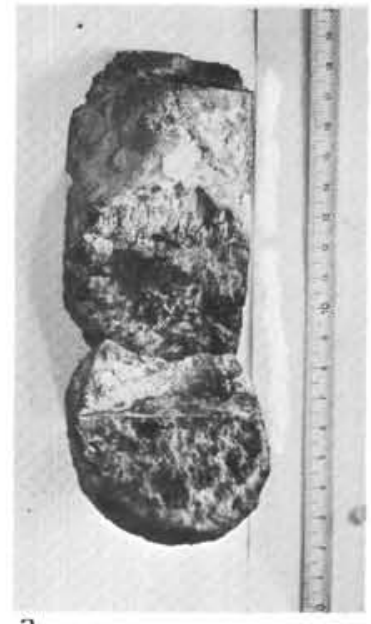

3

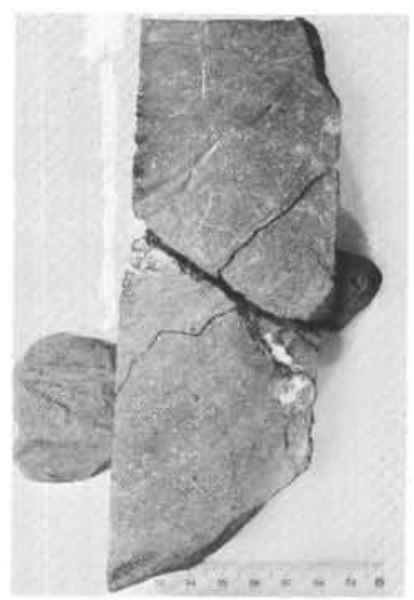

6
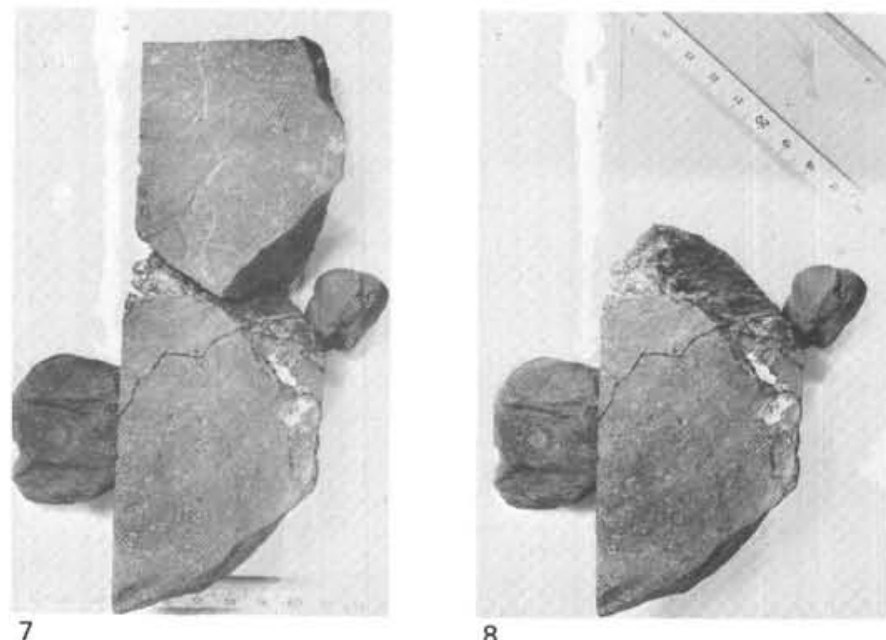

8

Photographs of specimens examined from Leg 51B, Hole 417D.

Figures 1-4 Piece 3 of Section 42-3.

Figures 5-8 Piece 8 of Section 44-3. For explanations, see text and Figures 3 and 4. 


\section{PLATE 2}
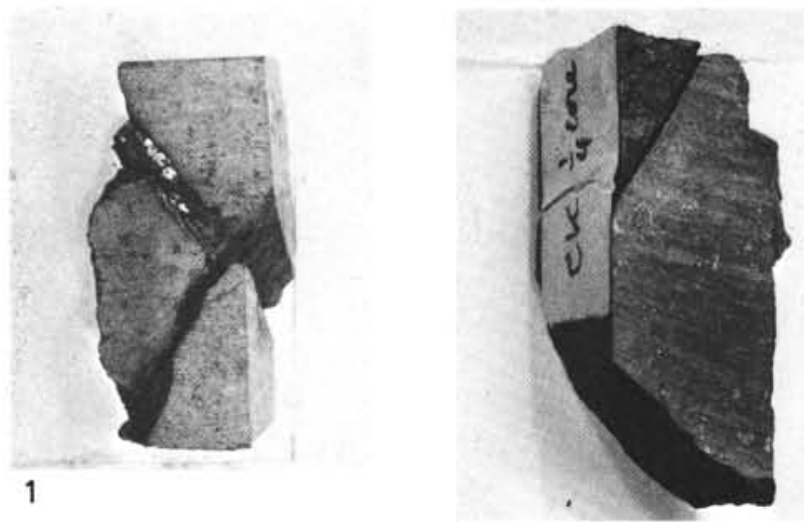

2

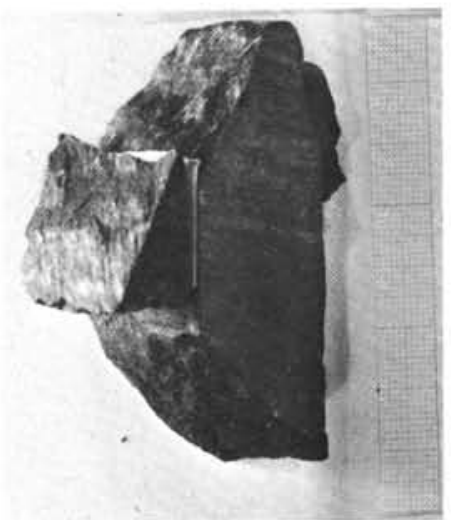

3
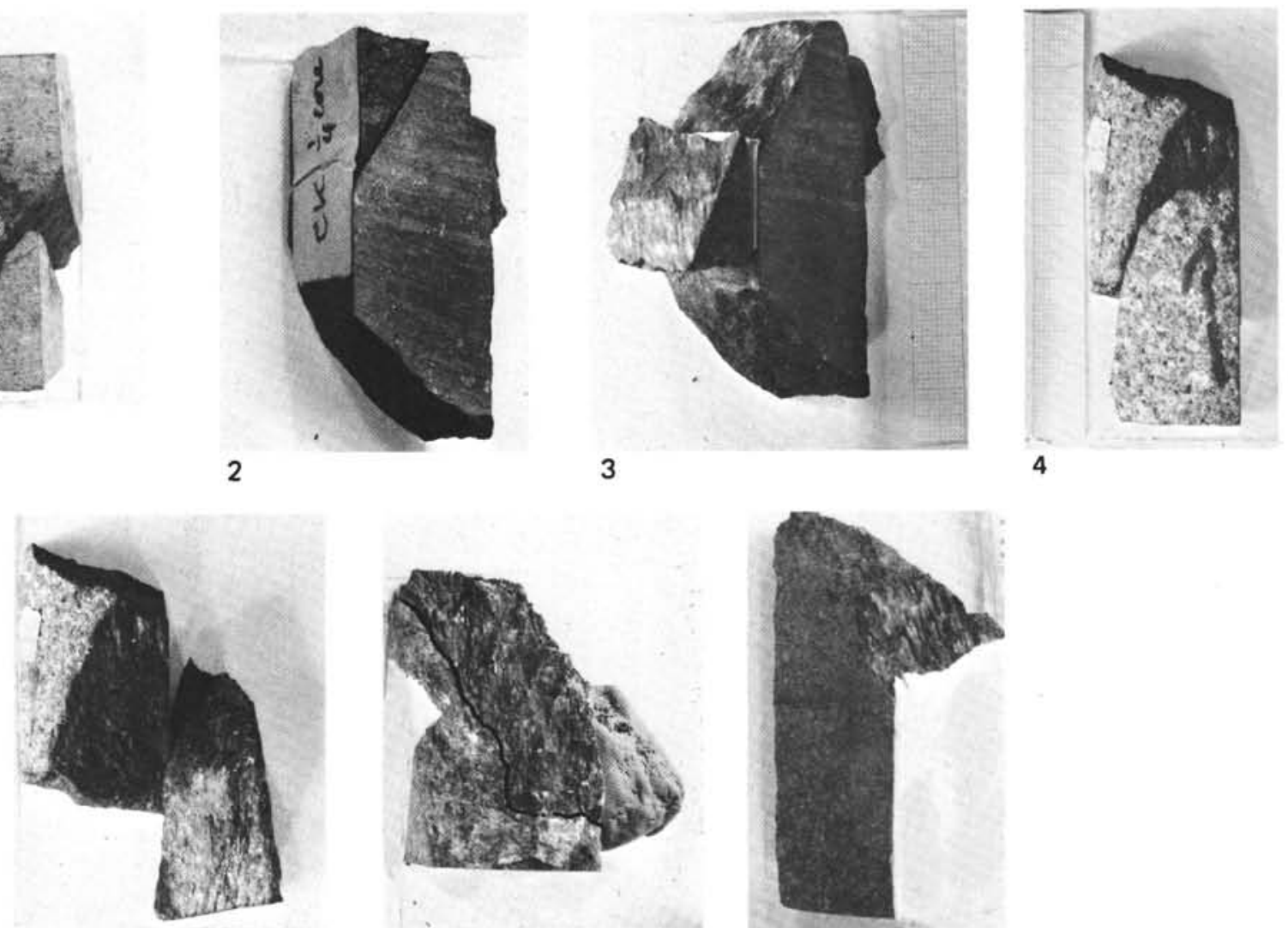

5
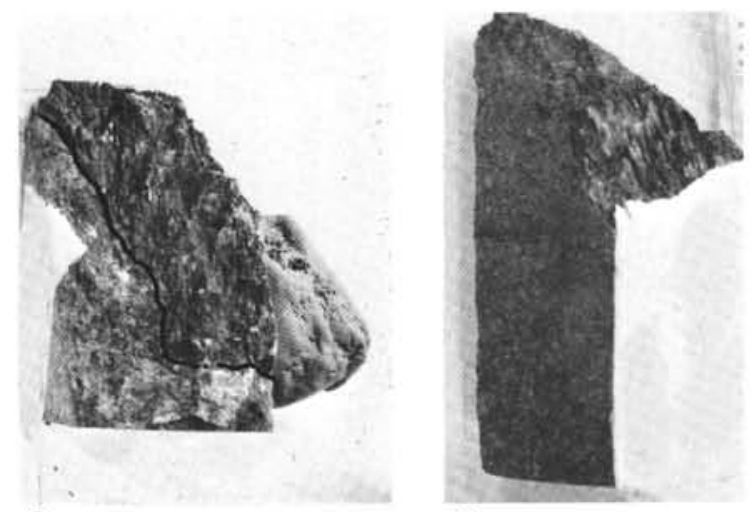

7

PLATE 2

Photographs of specimens examined from Leg 53, Hole 418A.

Figure 1 Sample $55-4,81-87 \mathrm{~cm}$. Note the relationship between a calcite-filled gash and the normal fault; see also Figure 5.

Figures 2, 3 Sample $65-4,21-26 \mathrm{~cm}$. Reference fault plane separates brecciated basaltic material (top left) from massive basalt (bottom right). Note the striation with a pitch of $70^{\circ}$ on the fault plane.

Figures 4, 5 Sample 84-1, 74-79 cm. Reverse fault coated with fibrous vermiculite.

Figure 6 Sample 85-2, 27-33 cm. Reverse fault with fibrous vermiculite. Note the relationship between the secondary crystallization zone and fresh rock (dark line marks the boundary).

Figure 7 Sample $85-5,122-129 \mathrm{~cm}$. Note the morphology of fibrous vermiculite implying the reverse motion of the missing upper block. 